\title{
Conversion of Perennial Ryegrass to Bermudagrass Using Seeded Cultivars, Herbicides, and Plant Growth Regulators
}

\author{
D.W. Williams ${ }^{1}$ and P.B. Burrus ${ }^{2}$ \\ Room N-222J Agricultural Science Building, Department of Agronomy, \\ University of Kentucky, Lexington, KY 40546-0091
}

Additional index words. Species conversion, seeded-bermudgrass

\begin{abstract}
Perennial ryegrass (PR) (Lolium perenne $\mathrm{L}$.) is often used as a low-mowed turf in the transition climatic zone. However, control of the fungal disease gray leaf spot (Pyricularia grisea (Cooke) Sacc.) has drastically increased the cost of PR management. Seeded bermudagrasses (SB) [Cynodon dactylon (L.) Pers.] are viable options for turfgrass management operations with limited pesticide budgets. Field trials in 2000 and 2001 tested the effects of two herbicides and several plant growth regulators (PGR) during renovation of mature PR to either of two cultivars of SB. The herbicides glyphosate and pronamide, and the PGR's trinexapac-ethyl, ethephon, paclobutrazol, and flurprimidol were applied at label rates to mature stands of PR. 'Mirage' and 'Yukon' SB were seeded separately either 1 or 7 days after applications (DAA) of chemicals. SB establishment, first-winter survival, and turfgrass quality (TQ) were rated and compared to an untreated control. Results indicated that only applications of glyphosate resulted in acceptable renovation of PR to SB, but also resulted in significantly lower $(P<0.05) \mathrm{TQ}$ during the transition. Applications of pronamide resulted in significantly less $(P<0.05)$ SB transition than did applications of glyphosate, but pronamide plots maintained higher TQ. None of the PRG treatements had a significant effect $(P<0.05)$ on SB transition. There were no consistent significant effects $(P<0.05)$ due to DAA among any of the chemicals evaluated. First-winter survival was significantly higher $(P<0.05)$ with 'Yukon' than with 'Mirage' in both years. We conclude that among the chemicals tested, only applications of glyphosate resulted in acceptable transition of PR to SB, but a significant reduction of $T Q$ should be expected during the transition. Chemical names used: [N-(phosphonomethyl) glycine] (glyphosate); [3.5-dichloro-N-(1,1-dimethyl-2-propynyl)benzamide] (pronamide); [(2-chloroethyl) phosphonic acid] (ethephon); [4-(cyclopropyl- $\alpha$ hydroxy-methylene)-3,5-dioxo-cyclohexane-cabroxylic acid ethyl ester] (trinexapac-ethyl);

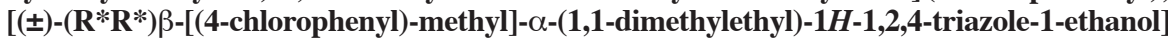
(paclobutrazol); [ $\alpha$-(1-methylethyl)- $\alpha$-[4-(trifluromethoxy)phenyl]-5-pyrmidinemethanol] (flurprimidol).
\end{abstract}

Perennial ryegrass (PR) (Lolium perenne L.) is a very popular species in the transition climatic zone. This is especially true when pesticide budgets are moderate to low. PR is a cool-season (C3) species, provides dark green color, high shoot densities, acceptable heat and drought tolerance, and is well-adapted to low mowing heights. Fungal diseases may cause severe damage to PR. PR is highly susceptible to brown patch (Rhizoctonia solani Kühn), pythium blight (Pythium sp.), and the emerging disease, gray leaf spot [Pyricularia grisea (Cooke) Sacc.]. These diseases can cause great damage to PR and may require regular fungicide treatments. Specifically, managing gray leaf spot with fungicides can be extremely expensive, thus negating one of the perceived benefits of PR as a low-mowed turf.

Received for publication 4 Aug. 2002. Accepted for publication 21 Apr. 2003. We gratefully acknowledge partial funding of this project by the United States GolfAssociation and the Kentucky Turfgrass Council. Discussions of herbicides and plant growth regulators imply no endorsement by the Univ. of Kentucky or its representatives. Criticism of products not listed is neither implied nor intended.

${ }^{1}$ Assistant Professor.

${ }^{2}$ Research Specialist.
Bermudagrass [Cynodon dactylon (L.) Pers.], a warm-season (C4) species, is also desirable as a low-maintenance turfgrass in the transition zone. This is mainly due to fewer pest problems and much higher water use efficiency relative to cool season species. Bermudagrass is at the peak of its annual growth curve in summer when many turf areas are receiving high usage. Cool season grasses (e.g., PR) are often experiencing environmental and/or pathogenic stresses during the same time. Bermudagrass is host to few fungal or insect pests in the transition zone, and allows costefficient and effective weed control strategies due to winter dormancy. Until recently, only bermudagrass cultivars that are vegetatively propagated have been successful and widely used in the transition zone. The main problems with these bermudagrasses are the costs and time required for vegetative establishment. All bermudagrasses managed as low-mowed turf in the transition zone are susceptible to the ever-present risk of winter-kill.

Work continues on improving seeded, warm-season grass cultivars through plant breeding efforts. In particular, much progress has been made in improving the turf quality and cold temperature hardiness of seeded-bermudagrasses (SB). Propagation of bermudagrass by seed is much faster and far less expensive than vegetative propagation. Hence, SB has become a desirable option for turfgrass managers wishing to renovate PR with a warm season species.

Renovation of any turf often requires application of herbicides to reduce or remove competition, thus allowing new seedlings to become established. Glyphosate is useful for three reasons. The effects of glyphosate are generally not visible for several days after application, unlike other nonselective herbicides (e.g., paraquat, glufosinate). If the new species is seeded soon after application, this may allow time for germination to occur before the effects of glyphosate become apparent. As such, the quality and utility of the turf during transition might suffer less. Secondly, several investigators (Egley and Williams, 1978; Hurto and Turgeon, 1978; Kaufman, 1978; Kollenkark and Daniel, 1978; Marshall and Naylor, 1984) have reported little to no effect on germination or establishment from applications of glyphosate, even when seeding is accomplished soon after application. Lastly, the non-selective activity of glyphosate provides excellent, often total control of most turfgrass species, including PR.

Pronamide is often used to selectively remove PR from existing stands of bermudagrass following winter overseeding (Horn, 1971; Mazur, 1988). However, pronamide is known to persist in soils for long periods of time (Ledeboer, 1973; Whitcomb and Horn, 1972). As with glyphosate, the effects of pronamide on PR are not immediately visible, and could allow bermudagrass germination and establishment before PR color and utility becomes unacceptable. The residual effects of pronamide on seedling bermudagrass are not well-known.

Several plant growth regulators are known to have activity on PR. Application of these products may reduce growth and thus competition from PR during bermudagrass germination and establishment without sacrificing PR color and playability. In general, PGRs exhibit activity for 3-4 weeks following application to turfgrasses, which may give an advantage to bermudagrass seedlings. PGRs may or may not also affect seedling bermudagrass during renovation. Jensen and Embree (1986) and Devlin and Koszanski (1985) reported that applications of paclobutrazol inhibited weed seed germination. Flurprimidol has also been reported to have an effect on seedling establishment (Delvin and Koszanski, 1985; Gaussoin and Branham, 1987). Ethephon has been reported to enhance germination in species exhibiting dormancy (Gul and Weber, 1998; Kepczski, and Bialecka, 1994). Less is known about the effects of trinexapac-ethyl during renovation from one species to another.

These experiments were designed to test practical chemical treatments to enhance establishment of SB in existing (mature) PR while evaluating overall turfgrass quality during the transition between species. Additionally, the timing of seeding following chemical applications was evaluated to test the residual effects on germination and establishment. The 
specific objectives of these experiments were to: 1) test herbicides known to have activity on PR to halt growth prior to renovation with SB and evaluate the residual effects of herbicides on SB establishment; 2) test PRG's to reduce or halt growth of PR prior to renovation with SB and evaluate residual PGR effects on SB establishment; 3) test the timing of seeding following chemical applications for successful transition of mature PR to SB as related to overall turfgrass quality during species transition; and 4) evaluate two SB cultivars during renovation of $\mathrm{PR}$.

\section{Materials and Methods}

Field trials were conducted at the Univ. of Kentucky Agricultural Experiment Station in Lexington, Ky. The experiments began in 2000 and were repeated in 2001 . The probability for successful establishment of SB in the transition zone is highest when soil temperatures are warm and maximum growth is allowed before entering the first winter (Patton et. al, 2002). To accomplish this, these experiments were established during the first week of June both years.

Chemical treatments consisted of six herbicides or plant growth regulators applied at label rates along with an untreated control. A preliminary study in germination chambers indicated that applications to bare soil (collected from the site of this field study) of some commonly used herbicides and one PGR resulted in unacceptable germination and/or seedling vigor of SB (data not shown). This initial chemical screening defined the treatments used in this field study. Chemicals were applied using a $\mathrm{CO}_{2}$-powered boom sprayer with 8004 flat fan nozzles with a carrier rate of $285 \mathrm{~L} \cdot \mathrm{ha}^{-1}$ at $207 \mathrm{kPa}$. The chemical treatments evaluated, their formulations, and application rates are listed in Table 1.

Seeded bermudagrasses used were the cultivars Mirage and Yukon. Seeding was accomplished by the following protocol (including chemically untreated controls): aerification $(1.2 \mathrm{~cm}$ diameter hollow tines, $10 \mathrm{~cm}$ depth, $5 \mathrm{~cm}$ tine spacing), vertical mowing $(\approx 6 \mathrm{~mm}$ depth, $5 \mathrm{~cm}$ blade spacing to break up aerification plugs), application of chemicals, and lastly broadcasting seed by hand to individual split-split plots as per timing treatments. Plots were then raked lightly by hand with an inverted spring-tine leaf rake. Timing treatments consisted of seeding either 1 or $7 \mathrm{~d}$ after applications (DAA) of chemical treatments. Chemically untreated plots were seeded at the same time

Table 1. Chemical treatments, formulations, and rates of products applied in experiments to renovate perennial ryegrass to seeded bermudagrass in 2000 and 2001.

\begin{tabular}{|c|c|c|}
\hline Chemical treament & Formulation & Rate \\
\hline Glyphosate & $4 \mathrm{SC}$ & $1.10 \mathrm{~L}$ \\
\hline Pronamide & $50 \mathrm{WP}$ & $0.75 \mathrm{~kg}$ \\
\hline Trinexapac-ethyl & $1.5 \mathrm{SC}$ & $0.50 \mathrm{~L}$ \\
\hline Ethephon & $2 \mathrm{SL}$ & $5.0 \mathrm{~L}$ \\
\hline Paclobutrazol & $2 \mathrm{SC}$ & $0.75 \mathrm{~L}$ \\
\hline Flurprimidol & $50 \mathrm{WP}$ & $0.55 \mathrm{~kg}$ \\
\hline $\begin{array}{l}\text { Untreated control: } \\
\text { No chemicals app }\end{array}$ & & \\
\hline
\end{tabular}

as plots receiving chemical applications. The seeding rate of pure live seed for both cultivars was $24.4 \mathrm{~kg} \cdot \mathrm{ha}^{-1}$, and nitrogen was applied as urea (46-0-0) at a rate of $48.8 \mathrm{~kg} \cdot \mathrm{ha}^{-1}$ once at seeding, and once every 2 weeks following seeding to all treatments until $15 \mathrm{Aug}$. each year (Munshaw, et. al., 2001). Irrigation was supplied immediately after seeding and as needed to support germination and growth of SB.

Trials were conducted in existing, pure stands of mature PR ( $>1$-year-old) maintained at a mowing height of $1.6 \mathrm{~cm}$. Plots were mowed $3 \mathrm{~d}$ per week prior to and during the experiments. The soil was a Maury silt loam (fine, mixed, mesic typic Paleudauf) with a $\mathrm{pH}$ of 6.4. Mehlich 3 soil tests showed that $\mathrm{P}$ and $\mathrm{K}$ levels were very high.

Transition from PR to SB and overall turfgrass quality (TQ) were evaluated regularly following treatments. Plots were rated for percent SB coverage (establishment) until the end of each growing season. TQ ratings were visual evaluations of the combination of turfgrass color, density, texture, and uniformity, each being considered equally. TQ was rated on a scale of $1-9$, where $1=100 \%$ dead turf, and 9 $=$ excellent quality. TQ was evaluated regardless of the predominant species, i.e., with no regard to successful transition from $\mathrm{PR}$ to $\mathrm{SB}$. $\mathrm{SB}$ winter survival was also rated as percent $\mathrm{SB}$ coverage in the spring of each year following renovation (2001 and 2002).

Experimental design was a randomized complete block with split-split plots and three replications. Whole plot treatments were SB cultivars $(25.6 \times 3 \mathrm{~m}$.), split-plots were chemical applications $(3.6 \times 3 \mathrm{~m})$, and split-split plots were timings of seeding following chemical applications $(1.8 \times 3 \mathrm{~m})$. The main effects and potential interactions of treatments on SB coverage were analyzed following arcsine transformation of percent of split-split plot area covered by SB. Statistical analyses were conducted using PROCANOVA of SAS (SAS, Cary N.C.). Means of nontransformed percentages of SB coverage and TQ were separated by F-protected least significant difference (LSD) tests $(\alpha=0.05)$.

\section{Results}

Bermudagrass transition. Analysis of variance (ANOVA) statistics for the main effects of treatments and potential interactions on arcsine transformed SB coverage data are presented in Table 2. To conserve space, only statistics for the last observations in each year and the first-winter survival ratings from the following spring seasons (2001/2002) are presented.

The main effects of chemical treatments on SB coverage were significant $(P<0.05)$ on all observation dates in 2000 , and on all but 1 early observation date in 2001. Plots treated with glyphosate had significantly higher percentages of SB coverage than all other chemical treatments. In 2000, the main effect of cultivars was significant on two early observation dates, and again on the last observation. This was due to faster germination of 'Mirage' early in the growing season, and then to the significantly higher winter survival of 'Yukon' the following spring (Tables 3 and 4). The same basic trend was present in 2001, with 'Mirage' establishing significantly faster, but not surviving the following winter as well as 'Yukon'. Additionally, 'Mirage' established significantly better than 'Yukon' in several treatment combinations in 2001, presumably due to faster germination (Tables 5 and 6).

There were no consistent, significant differences due to the main effect of DAA in either year of the study. The cultivar $x$ chemical interaction was significant at various levels on the last observation dates and for the ratings the following spring seasons in both years of the study. This is explained by the ranges of success of both cultivars within glyphosate and pronamide-treated plots relative to the lack of successful establishment in PGR treated plots and in the untreated controls.

Nontransformed percentages of SB plot coverage for 'Mirage' and 'Yukon' are presented in Tables 3 and 4 for 2000 , and in Tables 5 and 6 for 2001. These data also indicate that plots treated with glyphosate had significantly higher SB coverage than all other treatments. Plots treated with pronamide had significantly more SB than all PGR's and the untreated control, but significantly less than those treated with glyphosate. None of the PGR's applied resulted in significantly different percentages of SB coverage than the untreated control on any observation date in either year. There were no significant differences between cultivars in plots treated with glyphosate or pronamide when rated at the end of the 2000-growing season; i.e, within each individual herbicide treatment, both cultivars were equally well

Table 2. Analysis of variance (ANOVA) statistics for the main effects of treatments and potential interactions on arcsine-transformed percent seeded-bermuda grass coverage on the last observation dates in 2000 and 2001, and winter survival ratings taken the follow spring seasons (2001/2002).

\begin{tabular}{|c|c|c|c|c|c|c|c|c|}
\hline \multirow[b]{3}{*}{ Source } & \multicolumn{8}{|c|}{ Observation dates } \\
\hline & \multicolumn{2}{|c|}{1 Sept. 2000} & \multicolumn{2}{|c|}{21 Jun 2001} & \multicolumn{2}{|c|}{3 Oct. 2001} & \multicolumn{2}{|c|}{8 May 2002} \\
\hline & $\mathrm{F}$ & $\operatorname{Pr}>F$ & $\mathrm{~F}$ & $\operatorname{Pr}>F$ & $\mathrm{~F}$ & $\operatorname{Pr}>F$ & $\mathrm{~F}$ & $\operatorname{Pr}>F$ \\
\hline$\overline{\text { Block (rep) }}$ & 2.52 & 0.0900 & 0.99 & 0.3789 & 1.55 & 0.2222 & 0.64 & 0.5319 \\
\hline Cultivar (cult) & 0.80 & 0.3755 & 14.77 & 0.0003 & 82.05 & 0.0001 & 15.12 & 0.0001 \\
\hline Chemical (chem) & 123.10 & 0.0001 & 14.60 & 0.0001 & 30.37 & 0.0001 & 79.49 & 0.0001 \\
\hline Seed timing (DAA) & 0.32 & 0.5758 & 0.02 & 0.8990 & 0.70 & 0.4080 & 0.12 & 0.7296 \\
\hline Cult $\times$ chem & 2.14 & 0.0633 & 18.42 & 0.0001 & 2.96 & 0.0143 & 8.65 & 0.0001 \\
\hline Cult $\times$ DAA & 1.64 & 0.2058 & 0.11 & 0.7388 & 0.94 & 0.3367 & 0.54 & 0.4662 \\
\hline Chem $\times$ DAA & 0.89 & 0.5072 & 0.41 & 0.8701 & 0.38 & 0.8900 & 0.68 & 0.6637 \\
\hline Cult $\times$ chem $\times$ DAA & 0.35 & 0.9044 & 0.10 & 0.9965 & 0.77 & 0.6000 & 0.30 & 0.9325 \\
\hline$R^{2}$ & 0.93 & & 0.80 & & 0.84 & & 0.91 & \\
\hline $\mathrm{CV}(\%)$ & 25.6 & & 27.0 & & 25.5 & & 27.2 & \\
\hline
\end{tabular}


established. The same was true in 2001, except that where pronamide was applied, percent SB coverage with 'Yukon' was significantly less than in 'Mirage' plots.

'Mirage' did not survive the winter of 2000/2001 within any treatment combination, whereas 'Yukon' plots treated with glyphosate had a range of $42 \%$ to $46 \%$ plot coverage in
Spring 2001. Winter survival in the 2001 trial (rated in Spring 2002) was much improved for both cultivars. In glyphosate treated plots, percent SB coverage was $51 \%$ to $56 \%$ and $86 \%$ to $97 \%$ for 'Mirage' and 'Yukon', respectively. Additionally, in 'Yukon' plots where pronamide was applied, the percent coverage in Spring 2002 (37\% to 50\%) ap- proached the percent coverage of 'Mirage' in the glyphosate-treated plots.

Turf quality during and following bermudagrass transition. The ANOVA statistics for TQ ratings are presented for 2000 and 2001 in Tables 7 and 8, respectively. Again, to conserve space, only statistics for selected observation dates are given. As the point of interest rela-

Table 3. Mean percentages of bermudagrass coverage in plots seeded with 'Mirage' 1 or $7 \mathrm{~d}$ after application of chemical treatments in June 2000 and evaluated until the following spring.

\begin{tabular}{|c|c|c|c|c|c|c|c|c|c|c|c|}
\hline \multirow[b]{2}{*}{ Chemical } & \multirow[b]{2}{*}{ DAA $^{z}$} & \multicolumn{9}{|c|}{2000} & \multirow{2}{*}{$\frac{2001}{21 \text { June }}$} \\
\hline & & 26 June & 6 July & 17 July & 25 July & 1 Aug. & 9 Aug. & 17 Aug. & 22 Aug. & $1 \mathrm{Sept}$. & \\
\hline \multirow{3}{*}{ Untreated } & & & & & - Berm & idagrass & coverage & $\%)-$ & & & \\
\hline & 1 & 0 & 0 & 0 & 0 & 0 & 0 & 1 & 0 & 0 & 0 \\
\hline & 7 & 0 & 0 & 0 & 0 & 0 & 0 & 0 & 0 & 0 & 0 \\
\hline \multirow[t]{2}{*}{ Glyphosate } & 1 & 18 & 24 & 80 & 80 & 63 & 76 & 58 & 87 & 85 & 3 \\
\hline & 7 & 9 & 17 & 69 & 70 & 58 & 72 & 65 & 85 & 85 & 4 \\
\hline \multirow[t]{2}{*}{ Pronamide } & 1 & 1 & 4 & 4 & 7 & 11 & 10 & 18 & 22 & 21 & 0 \\
\hline & 7 & 2 & 11 & 11 & 23 & 18 & 28 & 25 & 31 & 35 & 1 \\
\hline \multirow{2}{*}{ Trinexapac-ethyl } & 1 & 0 & 0 & 0 & 0 & 0 & 0 & 0 & 1 & 0 & 0 \\
\hline & 7 & 0 & 0 & 0 & 0 & 1 & 0 & 4 & 3 & 5 & 0 \\
\hline \multirow[t]{2}{*}{ Ethephon } & 1 & 0 & 0 & 0 & 0 & 0 & 0 & 1 & 1 & 1 & 0 \\
\hline & 7 & 0 & 0 & 0 & 0 & 0 & 0 & 0 & 0 & 0 & 0 \\
\hline \multirow[t]{2}{*}{ Paclobutrazol } & 1 & 0 & 0 & 0 & 0 & 0 & 0 & 1 & 1 & 0 & 0 \\
\hline & 7 & 0 & 0 & 0 & 0 & 0 & 0 & 0 & 0 & 0 & 0 \\
\hline \multirow[t]{2}{*}{ Flurprimidol } & 1 & 0 & 0 & 0 & 0 & 0 & 0 & 0 & 0 & 0 & 0 \\
\hline & 7 & 0 & 0 & 0 & 0 & 0 & 0 & 0 & 0 & 0 & 0 \\
\hline $\operatorname{LSD}(\alpha=0.05)$ & & 2 & 2 & 5 & 18 & 11 & 9 & 14 & 7 & 9 & 10 \\
\hline
\end{tabular}

${ }^{2}$ DAA indicates the number of days after a chemical application that plots were seeded.

Table 4. Mean percentages of bermudagrass coverage in plots seeded with 'Yukon' 1 or $7 \mathrm{~d}$ after application of chemical treatments in June 2000 and evaluated until the following spring. Plots were seeded the first week of June.

\begin{tabular}{|c|c|c|c|c|c|c|c|c|c|c|c|}
\hline \multirow[b]{2}{*}{ Chemical } & \multirow[b]{2}{*}{$\mathrm{DAA}^{\mathrm{z}}$} & \multicolumn{9}{|c|}{2000} & \multirow{2}{*}{\begin{tabular}{|c|}
2001 \\
21 June
\end{tabular}} \\
\hline & & 26 June & 6 July & 17 July & 25 July & 1 Aug. & 9 Aug. & 17 Aug. & 22 Aug. & 1 Sept. & \\
\hline \multirow{3}{*}{ Untreated } & & & & & Berm & ddagrass & overage & \%) --- & -- & $\cdots$ & ---- \\
\hline & 1 & 0 & 0 & 0 & 0 & 0 & 0 & 0 & 0 & 0 & 0 \\
\hline & 7 & 0 & 0 & 0 & 0 & 0 & 0 & 0 & 1 & 0 & 0 \\
\hline \multirow[t]{2}{*}{ Glyphosate } & 1 & 13 & 14 & 42 & 32 & 58 & 80 & 63 & 79 & 83 & 42 \\
\hline & 7 & 11 & 14 & 42 & 38 & 73 & 83 & 68 & 87 & 92 & 46 \\
\hline \multirow{2}{*}{ Pronamide } & 1 & 1 & 1 & 4 & 13 & 6 & 3 & 13 & 15 & 13 & 10 \\
\hline & 7 & 3 & 1 & 5 & 5 & 8 & 5 & 15 & 16 & 13 & 8 \\
\hline \multirow[t]{2}{*}{ Trinexapac-ethyl } & 1 & 0 & 0 & 0 & 0 & 0 & 0 & 1 & 1 & 0 & 1 \\
\hline & 7 & 0 & 0 & 0 & 0 & 0 & 0 & 1 & 1 & 1 & 3 \\
\hline \multirow[t]{2}{*}{ Ethephon } & 1 & 0 & 0 & 0 & 0 & 0 & 0 & 0 & 0 & 0 & 0 \\
\hline & 7 & 0 & 0 & 0 & 0 & 0 & 0 & 0 & 0 & 0 & 0 \\
\hline \multirow{2}{*}{ Paclobutrazol } & 1 & 0 & 0 & 0 & 0 & 0 & 0 & 0 & 0 & 0 & 0 \\
\hline & 7 & 0 & 0 & 0 & 0 & 0 & 0 & 0 & 0 & 0 & 0 \\
\hline \multirow[t]{2}{*}{ Flurprimidol } & 1 & 0 & 0 & 0 & 0 & 0 & 0 & 0 & 0 & 0 & 0 \\
\hline & 7 & 0 & 0 & 0 & 0 & 0 & 0 & 0 & 0 & 0 & 0 \\
\hline $\operatorname{LSD}(\alpha=0.05)$ & & 2 & 2 & 5 & 18 & 11 & 9 & 14 & 7 & 9 & 10 \\
\hline
\end{tabular}

${ }^{2}$ DAA indicates the number of days after a chemical application that plots were seeded.

Table 5. Mean percentages of bermudagrass coverage in plots seeded with 'Mirage' 1 or $7 \mathrm{~d}$ after application of chemical treatments in June 2001 and evaluated until the following spring.

\begin{tabular}{|c|c|c|c|c|c|c|c|c|c|c|}
\hline \multirow[b]{2}{*}{ Chemical } & \multirow[b]{2}{*}{$\mathrm{DAA}^{\mathrm{z}}$} & \multicolumn{8}{|c|}{2001} & \multirow{2}{*}{$\begin{array}{l}2002 \\
8 \text { May }\end{array}$} \\
\hline & & 29 June & 18 July & 30 July & 9 Aug. & 22 Aug. & 5 Sept. & 17 Sept. & 3 Oct. & \\
\hline \multirow{3}{*}{ Untreated } & & & & & Bermuda & rass cove & (\%) & & & -- \\
\hline & 1 & 0 & 0 & 0 & 12 & 21 & 24 & 39 & 49 & 0 \\
\hline & 7 & 0 & 0 & 6 & 23 & 33 & 40 & 72 & 87 & 1 \\
\hline \multirow[t]{2}{*}{ Glyphosate } & 1 & 29 & 12 & 25 & 43 & 85 & 88 & 100 & 100 & 51 \\
\hline & 7 & 23 & 13 & 30 & 52 & 88 & 98 & 100 & 100 & 56 \\
\hline \multirow[t]{2}{*}{ Pronamide } & 1 & 0 & 5 & 11 & 14 & 42 & 63 & 90 & 92 & 15 \\
\hline & 7 & 0 & 3 & 26 & 46 & 78 & 90 & 95 & 100 & 20 \\
\hline \multirow[t]{2}{*}{ Trinexapac-ethyl } & 1 & 0 & 0 & 2 & 18 & 35 & 37 & 62 & 71 & 0 \\
\hline & 7 & 0 & 0 & 4 & 22 & 43 & 38 & 70 & 73 & 0 \\
\hline \multirow[t]{2}{*}{ Ethephon } & 1 & 0 & 0 & 12 & 19 & 25 & 29 & 58 & 68 & 0 \\
\hline & 7 & 0 & 0 & 9 & 20 & 34 & 24 & 51 & 70 & 0 \\
\hline \multirow[t]{2}{*}{ Paclobutrazol } & 1 & 0 & 0 & 2 & 12 & 22 & 19 & 38 & 45 & 0 \\
\hline & 7 & 0 & 0 & 4 & 15 & 26 & 25 & 55 & 47 & 0 \\
\hline \multirow[t]{2}{*}{ Flurprimidol } & 1 & 0 & 0 & 0 & 3 & 11 & 13 & 19 & 26 & 0 \\
\hline & 7 & 0 & 0 & 0 & 4 & 10 & 14 & 20 & 22 & 0 \\
\hline $\operatorname{LSD}(\alpha=0.05)$ & & 3 & 2 & 5 & 9 & 15 & 17 & 21 & 25 & 14 \\
\hline
\end{tabular}

${ }^{2}$ DAA indicates the number of days after a chemical application that plots were seeded. 
tive to TQ was a smooth transition from PR to $\mathrm{SB}$, and final TQ following renovation, statistics for the first three observation dates following chemical applications and the last observation dates in each year are presented. Mean TQ ratings for all observation dates in 2000 and 2001 are presented in Tables 9 and 10 and Tables 11 and 12 for 'Mirage' and 'Yukon', respectively.

The main effect of cultivars on TQ was significant only on the last observation in 2001. This was likely due to faster and more complete establishment of 'Mirage' in all nearly all treatment combinations, thus 'Mirage' plots exhibited significantly higher TQ.

The main effect of chemicals applied on TQ was highly significant very soon after application, with glyphosate-treated plots having significantly lowerTQ than all other treatments (Tables 9-12). At the end of both growing seasons, TQ in glyphosate treated plots was not significantly different than plots rated with the highest TQ. Plots treated with pronamide did not experience the same reduction of TQ as plots treated with glyphosate. However, TQ reductions in the pronamide treated plots relative to other treatments lasted longer into the growing season.

Other various significant differences in TQ were present throughout the study. In general, mean TQ ratings soon after chemical applications were ranked: glyphosate treated plots $<$ pronamide treated plots $<$ untreated controls $\leq$ PGR treated plots; with most significant differences diminishing as SB conversion advanced. Again, it is important to note that TQ was rated without regard to predominant species.

\section{Conclusions}

In both years of the study, and considering both cultivars, glyphosate was the most successful treatment in renovating PR to $\mathrm{SB}$. Plots treated with pronamide resulted in significantly more SB coverage than those untreated or treated with PGRs. However, the percent SB cover in pronamide treated plots was significantly less than the cover recorded in glyphosate plots. None of the PGR treatments resulted in significantly more bermudagrass conversion than the untreated controls in either year of the study.

There were no consistent differences comparing the days after chemical applications that plots were seeded for any of the chemicals tested. This work indicates that under the conditions of this study, timing of seeding after application was not crucial for the chemistries tested here.

It is also very clear from the data that 'Yukon'survived the winter following renovation significantly better than did 'Mirage'. In plots where bermudagrass became established, percent plot coverage was significantly higher in 'Yukon' plots than in 'Mirage' plots in the spring following renovation in both years of the study.

We noted significantly more bermudagrass coverage in 2001 than in 2000 when any of the same two treatment combinations were
Table 6. Mean percentages of bermudagrass coverage in plots seeded with 'Yukon' 1 or $7 \mathrm{~d}$ after application of chemical treatments in June 2001 and evaluated until the following spring.

\begin{tabular}{|c|c|c|c|c|c|c|c|c|c|c|}
\hline \multirow[b]{2}{*}{ Chemical } & \multirow[b]{2}{*}{ DAA $^{z}$} & \multicolumn{8}{|c|}{2001} & \multirow{2}{*}{$\frac{2002}{8 \text { May }}$} \\
\hline & & 29 June & 18 July & 30 July & 9 Aug. & 22 Aug. & 5 Sept. & 17 Sept. & $3 \mathrm{Oct}$. & \\
\hline \multirow{3}{*}{ Untreated } & & & & $--B$ & ermudag & ass cove & age (\%) & - & & \\
\hline & 1 & 0 & 0 & 0 & 14 & 23 & 22 & 38 & 27 & 9 \\
\hline & 7 & 0 & 0 & 0 & 12 & 22 & 19 & 35 & 19 & 2 \\
\hline \multirow[t]{2}{*}{ Glyphosate } & 1 & 40 & 10 & 11 & 16 & 42 & 73 & 87 & 96 & 97 \\
\hline & 7 & 28 & 5 & 10 & 18 & 30 & 62 & 80 & 88 & 86 \\
\hline \multirow[t]{2}{*}{ Pronamide } & 1 & 0 & 0 & 9 & 12 & 27 & 45 & 47 & 56 & 37 \\
\hline & 7 & 0 & 0 & 9 & 15 & 35 & 46 & 53 & 65 & 50 \\
\hline \multirow[t]{2}{*}{ Trinexapac-ethyl } & 11 & 0 & 0 & 1 & 11 & 14 & 16 & 23 & 15 & 8 \\
\hline & 7 & 0 & 0 & 0 & 11 & 10 & 20 & 28 & 15 & 6 \\
\hline \multirow[t]{2}{*}{ Ethephon } & 1 & 0 & 0 & 0 & 11 & 12 & 16 & 21 & 21 & 6 \\
\hline & 7 & 0 & 0 & 0 & 9 & 11 & 12 & 21 & 19 & 8 \\
\hline \multirow{2}{*}{ Paclobutrazol } & 1 & 0 & 0 & 0 & 5 & 3 & 9 & 12 & 9 & 4 \\
\hline & 7 & 0 & 0 & 0 & 4 & 6 & 8 & 17 & 12 & 3 \\
\hline \multirow[t]{2}{*}{ Flurprimidol } & 1 & 0 & 0 & 0 & 1 & 1 & 2 & 5 & 4 & 0 \\
\hline & 7 & 0 & 0 & 0 & 0 & 1 & 3 & 6 & 2 & 0 \\
\hline $\operatorname{LSD}(\alpha=0.05)$ & & 3 & 2 & 5 & 9 & 15 & 17 & 21 & 25 & 14 \\
\hline
\end{tabular}

${ }^{2}$ DAA indicates the number of days after a chemical application that plots were seeded.

Table 7. ANOVA statistics for the main effects of treatments and potential interactions on turfgrass quality rated on the first three and last observation dates in 2000.

\begin{tabular}{|c|c|c|c|c|c|c|c|c|}
\hline \multirow[b]{3}{*}{ Source } & \multicolumn{8}{|c|}{ Observation dates } \\
\hline & \multicolumn{2}{|c|}{26 June } & \multicolumn{2}{|c|}{6 July } & \multicolumn{2}{|c|}{17 July } & \multicolumn{2}{|c|}{1 Sept. } \\
\hline & $\mathrm{F}$ & $\operatorname{Pr}>\mathrm{F}$ & $F$ & $\overline{\mathrm{Pr}>\mathrm{F}}$ & $\mathrm{F}$ & $\operatorname{Pr}>\mathrm{F}$ & F & $\operatorname{Pr}>\mathrm{F}$ \\
\hline Block (rep) & 0.67 & 0.5180 & 2.22 & 0.1180 & 16.56 & 0.0001 & 1.25 & 0.2935 \\
\hline Cultivar (cult) & 4.83 & 0.0322 & 0.06 & 0.8066 & 0.96 & 0.3303 & 7.93 & 0.0068 \\
\hline Chemical (chem) & 114.04 & 0.0001 & 97.24 & 0.0001 & 86.64 & 0.0001 & 10.14 & 0.0001 \\
\hline Seed timing (DAA) & 0.02 & 0.8840 & 4.90 & 0.0311 & 3.33 & 0.0736 & 0.08 & 0.7719 \\
\hline Cult $\times$ chem & 2.88 & 0.0166 & 0.24 & 0.9624 & 1.19 & 0.3232 & 1.68 & 0.1433 \\
\hline Cult $\times$ DAA & 0.19 & 0.6619 & 0.54 & 0.4638 & 2.38 & 0.1285 & 0.24 & 0.6292 \\
\hline Chem $\times$ DAA & 0.07 & 0.9985 & 1.12 & 0.3607 & 0.25 & 0.9575 & 0.08 & 0.9975 \\
\hline Cult $\times$ chem $\times$ DAA & 0.14 & 0.9896 & 0.23 & 0.9662 & 0.22 & 0.9676 & 0.59 & 0.7385 \\
\hline$R^{2}$ & 0.93 & & 0.92 & & 0.91 & & 0.61 & \\
\hline $\mathrm{Cv}(\%)$ & 12.4 & & 13.6 & & 10.9 & & 20.1 & \\
\hline
\end{tabular}

Table 8. ANOVA statistics for the main effects of treatments and potential interactions on turfgrass quality rated on the first three and last observation dates in 2001.

\begin{tabular}{|c|c|c|c|c|c|c|c|c|}
\hline \multirow[b]{3}{*}{ Source } & \multicolumn{8}{|c|}{ Observation dates } \\
\hline & \multicolumn{2}{|c|}{29 June } & \multicolumn{2}{|c|}{18 July } & \multicolumn{2}{|c|}{30 July } & \multicolumn{2}{|c|}{3 Oct } \\
\hline & $\mathrm{F}$ & $\operatorname{Pr}>\mathrm{F}$ & $\mathrm{F}$ & $\operatorname{Pr}>\mathrm{F}$ & $\mathrm{F}$ & $\overline{\operatorname{Pr}>F}$ & $\mathrm{~F}$ & $\operatorname{Pr}>\mathrm{F}$ \\
\hline Block (rep) & 3.97 & 0.0247 & 3.17 & 0.0497 & 3.47 & 0.0383 & 1.57 & 0.2173 \\
\hline Cultivar (cult) & 1.73 & 0.1944 & 1.43 & 0.2374 & 0.10 & 0.7579 & 43.58 & 0.0001 \\
\hline Chemical (chem) & 128.29 & 0.0001 & 212.91 & 0.0001 & 27.13 & 0.0001 & 17.62 & 0.0001 \\
\hline Seed timing (DAA) & 2.70 & 0.1063 & 3.52 & 0.0659 & 0.10 & 0.7579 & 0.64 & 0.4271 \\
\hline Cult $\times$ chem & 1.41 & 0.2272 & 1.36 & 0.2478 & 2.59 & 0.0283 & 2.00 & 0.0810 \\
\hline Cult $\times$ DAA & 5.29 & 0.0254 & 0.03 & 0.8651 & 0.10 & 0.7579 & 1.00 & 0.3217 \\
\hline Chem $\times$ DAA & 0.49 & 0.8096 & 1.01 & 0.4288 & 0.49 & 0.8098 & 0.90 & 0.5039 \\
\hline Cult $\times$ chem $\times$ DAA & 0.82 & 0.5607 & 0.37 & 0.8955 & 0.74 & 0.6163 & 1.21 & 0.3153 \\
\hline$R^{2}$ & 0.94 & & 0.96 & & 0.78 & & 0.77 & \\
\hline $\mathrm{CV}(\%)$ & 10.1 & & 10.4 & & 20.6 & & 19.9 & \\
\hline
\end{tabular}

Table 9. Mean turf quality ratings in plots seeded with 'Mirage' 1 or $7 \mathrm{~d}$ after application of chemical treatments in June 2000 and evaluated until the following spring.

\begin{tabular}{|c|c|c|c|c|c|c|c|c|c|c|}
\hline Chemical & $\mathrm{DAA}^{\mathrm{z}}$ & 26 June & 6 July & 17 July & 25 July & 1 Aug. & 9 Aug. & 17 Aug. & $22 \mathrm{Aug}$ & 1 Sept. \\
\hline & & & & & & urf qua & ity ${ }^{y}-$ & & & \\
\hline \multirow{2}{*}{ Untreated } & 1 & 7.0 & 8.3 & 9.0 & 9.0 & 6.7 & 8.3 & 5.7 & 7.0 & 6.7 \\
\hline & 7 & 7.0 & 8.0 & 8.7 & 9.0 & 6.7 & 8.3 & 5.7 & 7.3 & 6.7 \\
\hline \multirow[t]{2}{*}{ Glyphosate } & 1 & 1.0 & 1.0 & 4.0 & 6.0 & 4.7 & 4.7 & 5.0 & 6.7 & 8.0 \\
\hline & 7 & 1.0 & 1.0 & 3.3 & 5.7 & 4.7 & 5.0 & 5.0 & 6.7 & 7.7 \\
\hline \multirow[t]{2}{*}{ Pronamide } & 1 & 7.0 & 5.7 & 5.7 & 5.3 & 4.7 & 6.0 & 5.7 & 6.0 & 5.7 \\
\hline & 7 & 7.0 & 5.7 & 5.0 & 5.3 & 4.7 & 5.3 & 5.3 & 5.7 & 6.0 \\
\hline \multirow{2}{*}{ Trinexapac-ethyl } & 11 & 7.6 & 8.7 & 9.0 & 8.3 & 6.7 & 8.0 & 5.3 & 6.0 & 5.3 \\
\hline & 7 & 7.3 & 6.7 & 7.7 & 7.0 & 6.0 & 6.0 & 4.7 & 5.0 & 5.0 \\
\hline \multirow[t]{2}{*}{ Ethephon } & 1 & 5.7 & 7.7 & 8.3 & 8.0 & 5.7 & 7.7 & 5.7 & 6.7 & 6.3 \\
\hline & 7 & 5.7 & 7.7 & 8.0 & 7.7 & 6.3 & 7.3 & 5.7 & 7.0 & 6.7 \\
\hline \multirow[t]{2}{*}{ Paclobutrazol } & 1 & 6.7 & 8.0 & 8.0 & 7.3 & 6.0 & 7.0 & 4.0 & 4.3 & 4.7 \\
\hline & 7 & 6.3 & 7.3 & 7.7 & 6.7 & 5.7 & 7.0 & 3.7 & 4.3 & 5.0 \\
\hline \multirow[t]{2}{*}{ Flurprimidol } & 1 & 6.0 & 8.0 & 8.7 & 7.3 & 6.7 & 7.3 & 4.7 & 4.7 & 5.0 \\
\hline & 7 & 6.3 & 7.0 & 8.3 & 7.3 & 6.0 & 7.3 & 4.3 & 4.7 & 4.3 \\
\hline $\operatorname{LSD}(\alpha=0.05)$ & & 1.2 & 1.4 & 1.3 & 2.1 & 1.6 & 2.1 & 1.7 & 2.2 & 1.8 \\
\hline
\end{tabular}

${ }^{2}$ DAA indicates the number of days after a chemical application that plots were seeded.

yTurf quality was rated on a scale of $1-9$ where $1=100 \%$ dead turf and $9=$ excellent quality. 
Table 10. Mean turf quality ratings in plots seeded with 'Yukon' 1 or $7 \mathrm{~d}$ after application of chemical treatments in June 2000 and evaluated throughout the growing season.

\begin{tabular}{lcccccccccc}
\hline Chemical & DAA $^{z}$ & 26 June & 6 July & 17 July & 25 July & 1 Aug. & 9 Aug. & 17 Aug. & 22 Aug. 1 Sept. \\
\hline \multirow{2}{*}{ Untreated } & 1 & 7.3 & 8.3 & 8.6 & 8.3 & 6.7 & 7.7 & 5.3 & 6.0 & 5.3 \\
& 7 & 7.7 & 8.0 & 8.3 & 8.0 & 6.7 & 7.0 & 5.3 & 5.7 & 5.7 \\
Glyphosate & 1 & 1.0 & 1.0 & 2.7 & 4.7 & 4.7 & 4.7 & 5.3 & 6.0 & 6.7 \\
& 7 & 1.0 & 1.0 & 2.3 & 5.3 & 5.0 & 5.3 & 5.3 & 6.3 & 7.7 \\
Pronamide & 1 & 7.0 & 6.0 & 5.7 & 5.7 & 5.0 & 5.7 & 5.7 & 6.0 & 6.0 \\
& 7 & 7.0 & 6.3 & 5.7 & 5.3 & 5.3 & 6.0 & 6.0 & 6.3 & 6.0 \\
Trinexapac-ethyl & 1 & 7.0 & 8.0 & 8.3 & 7.3 & 5.3 & 6.3 & 4.0 & 4.7 & 5.0 \\
& 7 & 7.7 & 7.3 & 8.3 & 7.3 & 6.0 & 6.7 & 3.3 & 4.3 & 5.0 \\
Ethephon & 1 & 5.3 & 7.3 & 8.0 & 7.3 & 5.7 & 6.0 & 3.7 & 4.3 & 4.3 \\
& 7 & 5.3 & 7.3 & 8.3 & 7.7 & 5.3 & 6.3 & 3.7 & 4.3 & 4.0 \\
Paclobutrazol & 1 & 7.7 & 8.0 & 8.0 & 7.0 & 6.0 & 6.7 & 3.7 & 4.7 & 5.0 \\
& 7 & 6.3 & 7.3 & 8.0 & 6.7 & 5.7 & 7.0 & 4.3 & 4.7 & 4.3 \\
Flurprimidol & 1 & 7.7 & 8.0 & 8.3 & 7.7 & 6.7 & 7.0 & 4.3 & 4.7 & 3.7 \\
& 7 & 7.7 & 7.3 & 8.3 & 7.3 & 6.7 & 7.0 & 4.3 & 4.7 & 4.7 \\
LSD $(\alpha=0.05)$ & & 1.2 & 1.4 & 1.3 & 2.1 & 1.6 & 2.1 & 1.7 & 2.2 & 1.8 \\
\hline
\end{tabular}

${ }^{2}$ DAA indicates the number of days after a chemical application that plots were seeded.

'Turf quality was rated on a scale of $1-9$ where $1=100 \%$ dead turf and $9=$ excellent quality.

Table 11. Mean turfgrass quality ratings in plots seeded with 'Mirage' 1 or $7 \mathrm{~d}$ after application of chemical treatments in June 2001 and evaluated throughout the growing season.

\begin{tabular}{|c|c|c|c|c|c|c|c|c|c|}
\hline Chemical & $\mathrm{DAA}^{\mathrm{z}}$ & 29 June & 18 July & 30 July & 9 Aug. & 22 Aug. & 5 Sept. & 17 Sept. & 3 Oct. \\
\hline & & & & & Turf $\mathrm{c}$ & uality ${ }^{y}$ & & & 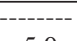 \\
\hline \multirow{2}{*}{ Untreated } & 1 & 6.7 & 7.7 & 7.0 & 5.7 & 4.3 & 3.7 & 4.3 & 5.0 \\
\hline & 7 & 7.7 & 7.3 & 5.7 & 4.7 & 4.3 & 5.0 & 6.3 & 7.0 \\
\hline \multirow[t]{2}{*}{ Glyphosate } & 1 & 1.3 & 1.0 & 3.3 & 4.3 & 5.7 & 7.3 & 8.0 & 8.0 \\
\hline & 7 & 1.7 & 1.0 & 3.6 & 5.0 & 6.0 & 7.0 & 8.0 & 8.0 \\
\hline \multirow{2}{*}{ Pronamide } & 1 & 7.7 & 3.7 & 2.0 & 2.3 & 3.7 & 5.7 & 7.0 & 7.3 \\
\hline & 7 & 7.3 & 3.7 & 3.3 & 4.0 & 5.0 & 7.0 & 7.7 & 8.0 \\
\hline \multirow{2}{*}{ Trinexapac-ethyl } & 1 & 7.3 & 7.3 & 6.0 & 5.0 & 3.7 & 4.7 & 5.7 & 6.7 \\
\hline & 7 & 7.3 & 8.0 & 6.7 & 5.0 & 5.0 & 5.0 & 5.7 & 6.3 \\
\hline \multirow{2}{*}{ Ethephon } & 1 & 6.3 & 7.3 & 6.7 & 5.3 & 5.0 & 4.0 & 5.7 & 6.3 \\
\hline & 7 & 6.7 & 7.7 & 6.7 & 5.3 & 5.0 & 5.3 & 5.7 & 5.7 \\
\hline \multirow[t]{2}{*}{ Paclobutrazol } & 1 & 8.0 & 7.0 & 5.3 & 4.7 & 4.0 & 4.0 & 4.7 & 4.7 \\
\hline & 7 & 7.7 & 7.3 & 4.7 & 4.7 & 4.3 & 4.3 & 5.3 & 6.0 \\
\hline \multirow{2}{*}{ Flurprimidol } & 1 & 7.7 & 7.3 & 5.3 & 4.7 & 3.7 & 3.7 & 3.0 & 4.3 \\
\hline & 7 & 7.3 & 8.3 & 6.0 & 5.3 & 3.7 & 4.7 & 3.7 & 4.3 \\
\hline $\operatorname{LSD}(\alpha=0.05)$ & & 1.1 & 1.0 & 1.7 & 1.5 & 1.9 & 2.0 & 1.7 & 1.8 \\
\hline
\end{tabular}

${ }^{2}$ DAA indicates the number of days after a chemical application that plots were seeded.

yTurf quality was rated on a scale of $1-9$ where $1=100 \%$ dead turf and $9=$ excellent quality.

Table 12. Mean turfgrass quality ratings in plots seeded with 'Yukon' 1 or $7 \mathrm{~d}$ after application of chemical treatments in June 2001 and evaluated throughout the growing season.

\begin{tabular}{|c|c|c|c|c|c|c|c|c|c|}
\hline Chemical & $\mathrm{DAA}^{\mathrm{z}}$ & 29 June & 18 July & 30 July & 9 Aug. & 22 Aug. & 5 Sept. & 17 Sept. & 3 Oct. \\
\hline & & & & & Turf & uality ${ }^{y}$ & & & \\
\hline \multirow[t]{2}{*}{ Untreated } & 1 & 7.7 & 7.0 & 6.7 & 4.3 & 4.3 & 4.3 & 4.7 & 5.0 \\
\hline & 7 & 7.3 & 7.3 & 7.0 & 5.3 & 4.7 & 4.7 & 4.0 & 4.7 \\
\hline \multirow{2}{*}{ Glyphosate } & 1 & 2.3 & 1.0 & 1.7 & 1.7 & 3.3 & 6.3 & 7.3 & 8.7 \\
\hline & 7 & 1.3 & 1.0 & 2.0 & 1.7 & 3.0 & 5.7 & 7.0 & 7.0 \\
\hline \multirow[t]{2}{*}{ Pronamide } & 1 & 7.7 & 4.0 & 3.7 & 2.3 & 3.3 & 4.0 & 4.7 & 4.3 \\
\hline & 7 & 7.0 & 3.7 & 3.3 & 2.0 & 3.3 & 4.7 & 5.7 & 5.3 \\
\hline \multirow[t]{2}{*}{ Trinexapac-ethyl } & 1 & 8.0 & 7.0 & 5.3 & 4.7 & 4.3 & 3.7 & 3.7 & 4.0 \\
\hline & 7 & 7.3 & 8.0 & 5.7 & 5.0 & 4.7 & 4.0 & 4.0 & 4.0 \\
\hline \multirow[t]{2}{*}{ Ethephon } & 1 & 8.0 & 7.7 & 6.0 & 4.3 & 3.7 & 4.0 & 3.7 & 4.0 \\
\hline & 7 & 7.0 & 7.7 & 6.0 & 5.3 & 4.0 & 4.3 & 51 & 4.7 \\
\hline \multirow[t]{2}{*}{ Paclobutrazol } & 1 & 7.7 & 8.0 & 6.0 & 4.3 & 4.3 & 3.7 & 3.3 & 4.0 \\
\hline & 7 & 7.3 & 8.3 & 5.7 & 4.3 & 4.0 & 3.7 & 3.3 & 3.7 \\
\hline \multirow[t]{2}{*}{ Flurprimidol } & 1 & 7.3 & 8.0 & 6.3 & 4.3 & 3.3 & 3.3 & 2.7 & 3.0 \\
\hline & 7 & 7.3 & 8.3 & 6.0 & 4.3 & 3.3 & 4.0 & 3.0 & 3.3 \\
\hline $\operatorname{LSD}(\alpha=0.05)$ & & 1.1 & 1.0 & 1.7 & 9 & 1.9 & 2.0 & 1.7 & 1.8 \\
\hline
\end{tabular}

${ }^{2}$ DAA indicates the number of days after a chemical application that plots were seeded.

yTurf quality was rated on a scale of $1-9$ where $1=100 \%$ dead turf and $9=$ excellent quality.

compared. This was likely due to increased disease pressure on PR from gray leaf spot in 2001. The 2001 renovation study was located adjacent to a gray leaf spot study where $P$. grisea inoculum was applied in July. Stress on PR resulting from gray leaf spot likely reduced shade and competition, much like herbicides alone would, and thus improved bermudagrass establishment in all treatments during the growing season of 2001.

We conclude that applications of glyphosate will result in successful renovation of PR to SB. However, plots treated with glyphosate did not result in a smooth TQ transition from PR to SB. Pronamide applied at label rates also resulted in significant SB establishment compared to untreated controls with a much smoother transition of TQ, but was not as successful in total renovation as were glyphosate treated plots. Glyphosate plots were totally necrotic $(\mathrm{TQ}=1)$ before SB germination and establishment. This lack of smooth TQ transition is normally considered a strong negative component of renovation activities. Significant SB coverage (20\% to $40 \%$ ) was noted in $20-25$ $\mathrm{d}$ following applications of glyphosate in both years of the study, with $58 \%$ to $88 \%$ SB coverage by mid-August. Renovation of PR to SB was most successful using glyphosate, but glyphosate should be expected to cause a significant reduction in TQ (mainly due to color) for up to $60 \mathrm{~d}$ following application, regardless of SB cultivar.

\section{Literature Cited}

Delvin, R.M. and Z.K. Koszanski. 1985. Effect of paclobutrazol and flurprimidol on the germination and growth of wheat and radish. p. 237-242. 12th Annu. Mtg. Proc. Plant Growth Regulat. Soc. Amer.

Egley, G.H. and R.D. Williams. 1978. Glyphosate and paraquat effects on weed seed germination and seedling emergence. Weed Sci. 26(3):249-251.

Gaussoin, R.E. and B.E. Branham. 1987. Annual bluegrass and creeping bentgrass germination response to flurprimidol. HortScience 22:441-442.

Gul, B. and D.J. Weber. 1998. Effect of dormancyrelieving compounds on the seed germination of non-dormant Allenrolfea occiddentalis under salinity stress. Ann. Bot. 82(5):555-560.

Horn, G.C. 1971. Control of weeds in warm season grasses with herbicides. Univ. of Florida Inst. of Food and Agr. Sci. Annu. Res. Rpt. p. 126.

Hurto, K.A. and A.J. Turgeon. 1978. Impact of thatch on residual activity of herbicides used in turgrass renovation. p. 50. $1977 \mathrm{Mtg}$. Weed Sci. Soc. Amer. Abstr.

Jensen, K.I.N. and C.G. Embree. 1986. Effect of soilapplied paclobutrazol on orchard weeds.p. 89 . Annu. Rpt., Res. Sta., Kentville, Nova Scotia.

Kaufman, J.E. 1978. Turfgrass renovation with glyphosate. p. 51. 1977 Mtg. Weed Sci. Soc. Amer. Abstr.

Kepczski, J. and B. Bialecka. 1994. Stimulatory effect of ethephon, ACC gibberellin $\mathrm{A}_{3}$ and $\mathrm{A}_{4+7}$ on germination of methyl jasmonate inhibited Amaranthus caudatus L. seeds. Plant Growth Regulat. 14(3):211-216.

Kollenkark, J. and W.H. Daniel. 1978. Glyphosate and its effect on seed germination. p. 6. 1977 Mtg. Weed Sci. Soc. Amer. Abstr.

Ledeboer, F.B. 1973. Control of Pоа аппиа on overseeded putting greens. p. 25. $1973 \mathrm{Mtg}$. Weed Sci. Soc. Amer. Abstr.

Marshall, A.H. and R.E.L. Naylor. 1984. The effect of leachates from grass trash on establishment of ryegrass. Ann. Applied Biol. 105(1):75-86.

Munshaw, Gregg C., David W. Williams, and Paul L. Cornelius. 2001. Management strategies during the establishment year enhance production and fitness of seeded bermudagrass stolons. Crop Sci. 41:1558-1564.

Patton, A.J., Z.J. Reicher, G.A. Hardebeck, and D.W. Williams. 2002. Effects of seeding date on bermudagrass and zoysiagrass establishment. Agron. Abstr. C05-patton08134oral.

SAS Institute. 1985. SAS user's guide: Statistics. 5th ed. SAS Inst., Cary, N.C.

Whitcomb, C.E. and G.C. Horn. 1972. Weed control for ornamental plants. Univ. of Florida Inst. of Food and Agr. Sci. Annu. Res. Rpt. p. 137. 